\title{
PSYCHOSEMANTIC SPACE OF DIFFERENT LEVELS OF THE STUDENT YOUTH MORAL STABILITY
}

https://doi.org/10.37096/SHDISJ-19-1.1-0007

\author{
Savelyuk Natalia, \\ https://orcid.org/0000-0001-5246-9677 \\ Tymosh Yulia \\ https://orcid.org/0000-0002-2394-8588
}

\begin{abstract}
The article deals with theoretical-empirical measurements of the psycho-semantic space of different levels of moral consciousness of the individual as a specific, cultural and individual due to the construct of its integral psyche. The category of significance is substantiated theoretically as the basic unit of scientific study and analysis of the defined sphere. The denotative and connotative, as well as associative meaning as the embodiment of the unity of a rational component in any sense with its rational, intuitive-sensual foundation, are described.

As a result of the systematic theoretical and empirical study of the problem, the psycho-semantic organization of moral consciousness is presented through a description of its psycho-semantic space. The psycho-semantic space of the moral consciousness of the student's personality is defined as an individual system of values in the totality of the corresponding individual and cultural heritage of the individual, structured in the sensual fabric of consciousness in the form of associative meanings of the notion of morality, the most frequent of which is the "conscience." Also, the connotative meanings of the basic notion of conscience on the three main levels of moral consciousness development in student youth were identified and interpreted: with leading evaluation and dynamically active connotations - at the preconventional level, with strong and ambivalent evaluative connotations - at the conventional level, positively evaluated and large-scale connotations - at the post-conventional level.
\end{abstract}

Keywords: meaning, associative meaning, connotative value, moral consciousness, preconventional level, conventional level, post-conventional level.

\section{Introduction}

The problem of moral development and selfdevelopment of the individual has always been one of the most urgent. After all, in the middle layers of the human psyche in different age periods, the violent "Id", which requires a rather strong counterweight, is developed by the "Super-Ego" on a regular and often powerful basis. And that is why morality, moral consciousness and selfconsciousness have always been considered as the most important foundation of man as an individual and a guarantee of its harmonious development in society.

At the same time, there has been a recent weakening of the moral component of relations between people, which is connected with the general deterioration of the political, economic and criminal situation both in Ukraine and in general on the whole. Unfortunately, the realities of life and information about them are full of events, the common names of which are often voiced as "war", "terrorism", "fraud", "corruption", etc. In addition, modernity has brought new "advanced" types and techniques of violations of moral norms of human coexistence for example, the notorious cyberbullying.

1. Despite the existing thorough research of morality, there is still no comprehensive study of the levels of moral development of contemporary Ukrainian youth in the scientific literature. Thus, in psychology, the features of moral development in preschool and junior school age, which are considered to be sensitive to the formation of moral consciousness and self-consciousness, are thoroughly investigated (Bekh, 2006; Borishevsky, 2010; Pavelkiv, 2015: 24-38; Savchyn, 2013); Scientists also touch upon the specifics of the moral development of adolescents, since the period is rather complex (Bekh, 2006; Vlasova, Meniailo, 2016). At the same time, in the conditions of crisis reforming of our society youth, youth, in particular student, often appear as an active driving force of various changes. As you know, it was the student waves of socio-political protests that launched at one time events of more than one Ukrainian "square". Therefore, a thorough and systematic scientific research of the moral consciousness of youth is needed as a criterion and indicator of the true psychological 
context of its various activities - civil, national, political, and religious ones.

The basic psychological vectors of the study of morality and moral consciousness, selfconsciousness of the individual are laid in the leading directions of psychological science: psychodynamic, behavioral, humanistic, cognitive and activity. In modern Ukrainian psychology, the problem of morality and moral development is also studied quite thoroughly and versatilely. The most fundamental principles of the study of the moral consciousness of the individual form the domestic concepts of I. Bech, M. Boryshevsky, O. Vlasova, R. Pavelkiv, M. Savchyn and others (Bekh, 2006; Borishevsky, 2010; Pavelkiv, 2015: 24-38; Savchyn, 2013; Vlasova, Meniailo V, 2016). Due to these and other studies, many important lines of moral development of the individual have been studied, but the realities of today are forced to look for new aspects in the coverage of the nature of morality, the essence of external social requirements and their harmonious combination with the tasks of individual formation, self-development, socio-historical and ontogenetic evolution of understanding of moral categories and concepts.

Note that in our study for the general theoretical basis, the definition of moral consciousness by R. Pavelkiv, which considers it as a special construct of the psyche, provides understanding and adoption of moral laws and the organization of personality in accordance with their own behavior (Pavelkiv, 2015: 24-38). Although some scholars still have an idea of the fundamental uncertainty of consciousness, including moral, standardized psychological techniques; others consider it possible to constructively solve this problem by means of modern psycho-semantics, which studies the genesis, structure and functioning of an individual system of meanings. In general, it combines different traditions of applying standardized and projective methods. Since the main task of psychosemantics is the reconstruction of an individual system of meanings, through which prism is the perception of the subject of the world, such an approach is considered as the embodiment of the subjective paradigm in psychology.

Specificity of consciousness in the reflection of the world is realized through values. The function of the value lies in the cultural structuring of sensory images of consciousness: it is through it that the subject assimilates fixed socio-historical experience of knowledge. According to the activity concept of consciousness, passage of meaning through the prism of the active subject perception, forms a personal meaning. Personal meaning is a "significance of meaning", that is, the functioning of value, in the system of social relations, on the one hand, and in the individual consciousness of an individual, on the other hand.

2. A thorough description of various types of meanings is offered in modern psycholinguistic studies. In particular, the connotative value, according to C. Osgood, is a universal value, which in any language can be described by the following three main parameters: strength, activity, evaluation (Osgood, 1975). Connotative significance, in contrast to the denotative, expresses the emotional attitude of the subject to objects of real reality, indicating the subjective acceptance or rejection of a particular life situation and events. It is primary, rational and serves as the prerequisite for the further creation of the logical meaning of the word. The basis of the connotative value, which is considered to be genetically the earliest form, is an experience in which the reflection and emotional attitude, the personal meaning and sensual tissue are still much differentiated. According to the psychology of subjective semantics and psycho-semantics, the structuring of meaning occurs as a result of "identification of the object of perception or the situation with the aftermath of the emotional state" (Artemieva, 2007). The associative meaning lies at the heart of the associative approach to the study of the meaning of the word. According to this approach, an important component of meaning is a number of associative relationships of a certain notion. As V. Petrenko notes, the associative technique reflects both cognitive structures that are beyond the verbal meanings, as well as the individual peculiarities of certain individuals (Petrenko, 2012).

Consequently, the purpose of the article is to describe the results of the study of associative and connotative meanings in the psycho-semantic structure of students' moral consciousness.

\section{Methodology}

The results of the theoretical analysis of the category of significance in the history of psychology and at the present stage of its development make it possible to determine the general methodological guidelines for the study of 
psycho-semantic space of students' moral consciousness. They are based on the consideration of the consciousness of the individual in general as a complex categoricalsemantic system, that is, an integral set of individual values with their corresponding sensual images. It was important for us to compare the psychological differences of this system at different levels of development of moral consciousness of the individual. Therefore, the basis of the empirical study was laid the wellknown method of "moral dilemma" L. Kohlberg (Dermanova, 2002: 103-112). Further, according to the results of the statistical processing of the relevant data of the study, the value of the percentiles has been determined and thus the low, medium, high degree of formation of preconvention, convention and post-convention levels of students' moral consciousness is determined.

3. In the study of the actual sensory tissue of moral consciousness, in particular associative significance, the procedure of the classical free associative experiment (Petrenko, 2012) was used. In our study, an associative experiment was used along with the method of incomplete sentences to identify associations for the keyword-stimulus "morality". Investigators were asked to write an association, which is the first to fall into their minds when presenting the word-stimulus. Subsequently its associative values were determined on the basis of the frequency of their use in students separately with pre-convention, convention and post-convention levels of moral consciousness development.

For further research and construction of the semantic differential of student consciousness, we chose the classical scale developed by C. Osgood, with the factors "estimation", "strength", "activity" (Osgood, 1975). It was used to compare connotative meanings as the expression of the sensory tissue of the moral consciousness of preconvention, convention, and post-convention students.

For this study, an association was chosen that most often used by students of all levels of development of moral consciousness on the wordstimulus "morality": conscience. According to the chosen method, respondents scaled this concept on a 7-digit scale (with a score of -3 to +3 ). Based on the similarity of the estimates, a matrix of distances of the scale was constructed, which was further subjected to the process of factor analysis with varimax-rotation. Mathematical and statistical processing of all data was carried out using the SPSS software.

The sample consisted of 114 students of Taras Shevchenko Kremenets Regional Humanitarian and Pedagogical Academy (aged 17-22) and 149 students of Lesia Ukrainka Eastern European National University (17-25 years old). Together 263 people.

\section{Results}

Consider the psycho-semantic space of the notion of "morality" for those who have shown a high degree of formation of only one level of moral development: pre-convention, convention, or postconvention, and at other levels have shown a low or middle degree of formation, in order to determine the psychological coordinates of morality precisely in these individuals.

The number of students, who revealed a high level of development of only one level of development of moral consciousness, totaled 104 people, among them: with a high preconceptional level formation - 38 people, the conventional level - 26 people, post-conventional level - 40 people.

According to the results obtained, we hypothesized that, given the high degree of formation of the post-conventional level of moral consciousness, other levels, leaving some of their elements in the structures of post-convention moral consciousness, are generally not expressed. It is also notable that out of 230 subjects less than half (104 persons) have a pronounced degree of formation (high) of a certain level of moral consciousness, while other respondents are a kind of combined types, while simultaneously embodying approximately the same degrees of development of the development of its various levels.

We believe that the most informative data in the study of the psycho-semantic space of moral consciousness will be the indicators obtained in the study of the moral consciousness of students with an expressed degree of formation of one or another of its levels, since the combined types do not make it possible to determine the psychosemantic organization of the moral consciousness of the person sufficiently clearly.

In addition, as noted above, although in structures of moral consciousness of a certain level there are elements of previous levels, the levels of moral consciousness differ qualitatively in their 
content. Therefore, we assumed a difference in the organization of the sensory tissue of the moral consciousness of the pre-convention, convention and post-convention levels. This fact made it possible to combine students with an expressed formation of different levels of moral consciousness to study its psycho-semantic space.

It should be noted, first of all, that identical associations with high frequency are recorded in respondents with different levels of moral consciousness, among them: conscience, courtesy, honesty. The shared semantic universals of morality for the investigated individuals in our opinion suggest in favor of the simultaneous expression of different levels of moral consciousness among students and the manifestation possibility of these different levels, depending on the situation. This is a coherent guiding principle of psycho-semantic research the principle of mediated activity, which manifests the appearance of moral consciousness in a particular type of activity in accordance with the current situation.

At the same time, there are differences that express the specifics of each of the levels studied. So, at the preconventional level, we see associations: help, person, friend, well-being,

partner, which testify to the importance of mutually beneficial relationships, the presence of well-being and comfort that bring pleasure. At persons with a standard level we observe associations: the law, rule, justice, which testify to the mood of students on social norms, orientation on a certain common good. At the postconventional level: goodness, dignity, honor, freedom, love, beauty, which did not occur at previous levels. Consequently, the postconventional level of moral consciousness expresses the greatest orientation of students to the search for universal truths. A meaningful analysis of associations confirms the qualitative interpretation of each level and expresses the specific features of the students' moral consciousness.

In addition, according to the instruction of C. Osgood's method, the respondents scaled the notion of conscience as the most common for all groups of the ruling association on the wordstimulus "morality" on 7-scale scales. Based on the similarity of the estimates, a matrix of distances of the scale was constructed, which was further subjected to the process of factor analysis with varimax-rotation (Table 1 ):

Table 1

\section{Factor loads of the main scales of semantic differential at different levels of development of moral consciousness}

\begin{tabular}{|c|c|c|c|}
\hline \multirow{2}{*}{$\begin{array}{c}\text { Semantic } \\
\text { differential scales }\end{array}$} & \multicolumn{3}{|c|}{ Factor loads: } \\
\hline & At the preconventional level & $\begin{array}{c}\text { At the conventional } \\
\text { level }\end{array}$ & $\begin{array}{c}\text { At the post-conventional } \\
\text { level }\end{array}$ \\
\hline good & 994 & ,922 & 981 \\
\hline beautiful & ,937 & ,937 & ,982 \\
\hline pleasant & ,995 & ,995 & , 481 \\
\hline strong & ,420 & ,920 & 199 \\
\hline big & ,994 & ,294 & 981 \\
\hline difficult & 194 & 394 & 085 \\
\hline fast & ,994 & 194 & 085 \\
\hline active & ,994 & 194 & 085 \\
\hline dynamic & ,494 & ,192 & 085 \\
\hline
\end{tabular}

The statistical processing made it possible to find out that the students of the preconventional level of the development of moral consciousness are the most expressive of the factor of evaluation of this concept in the categories pleasant, beautiful and good, as well as the force factor - active, big and fast. In general, the connotative meaning of the concept of conscience is distributed in twodimensional psycho-semantic space based on the basic factors, which are termed both evaluative and dynamically active.

As it is seen, the psycho-semantic space of students' moral consciousness with a preconventional level at the level of sensory tissue reflects the orientation of the subject to their own physical or hedonistic (associated with the desire to meet or avoid dissatisfaction) the consequences of the actions performed (encouragement, punishment, favoritism, etc.), and also on the 
authority and authority of those who have established these rules and regulations.

In other words, for a preconventional level of moral consciousness, an action which, at the same time, helps to meet the needs of both the individual and other people, the understanding of the interaction of people according to the rule "you me, and I - you", which is compared with the interpretation of conscience as the most frequent association in measurements pleasant, good, nice (as an orientation to oneself) and active, strong, fast (as an orientation to the reaction of others).

In the psycho-semantic space, the notion of conscience among students at the conventional level of development of moral consciousness was the most pronounced factor of strength (strong), as well as ratings in the categories pleasant, beautiful and good with the explicit at the same time and its negative pole. Thus, the connotative meaning of the notion of conscience at this level of development of the moral consciousness of students' functions in a two-dimensional space based on factors that we have described as strong and ambivalent-evaluative.

As is well-known, the orientation towards the pursuit of the ideal and adherence to high standards is inherent in the conventional level of moral consciousness (McLeod S. Kohlberg's, 2013). Thus, the focus on the requirements of "law and order" predetermines human behavior in the direction of fulfilling duties and monitoring the implementation of the established procedure for the sake of the order. It is advisable to foresee that in such a direction, reproaches of conscience can be observed in the event of a personal inconsistency with a certain ideal or in the case of non-compliance with moral requirements, which, in our opinion, determines the ambivalence of the factor of estimation of the concept of conscience among students of the standard level of moral consciousness.

It was noteworthy that the evaluation scale here was heavy, which is pronounced in students both preconventional and conventional levels, while at the precautionary level, the factor loads for this variable are higher. The positive pole of the expression of the corresponding connotative characteristic is consistent with our previous conclusions that the preconventional level has the most pronounced dynamic character and includes a focus on finding universal values as the core of the moral consciousness of the student population studied.

The dynamism of the preconventional level is expressed in the high factor loads of the variable of activity among students, whereas on the conventional level of bright expression the variable force becomes, which makes this stage psychologically more static, in comparison with the preconventional level.

In the psycho-semantic space, the concept of conscience among students of the postconventional level of development of moral consciousness is the most pronounced factor of evaluation with variables good, as well as forces with a variable large. Accordingly, we named these factors as positive-estimated and large-scale. Thus, the connotative meaning of the concept of "conscience" at this level functions in a twodimensional space with two basic factors, which means, first, the assessment of conscience only in positive categories and, secondly, the significance of its psycho-semantic space in the sense of the influence of moral truths.

The psycho-semantic space of students' moral consciousness with the post-conventional level of moral consciousness at the level of sensory tissue is compared with the characteristics described above of this level of consciousness as one that is oriented towards establishing the very universal moral values for the subject, regardless of the specifics of life situations. That is why the magnitude of conscience is consistent with the existence of an autonomous moral of man, defined by the universal humanistic, ethical principles of justice, goodness, faith, beauty, etc. This, obviously, determines an exclusively positive pole of the estimated factor. Significant here is a low load of variable power that is not essential for people with a post-conventional level.

\section{Discussion}

Thus, the category of meaning can serve as the unit of study of consciousness, in our case, of moral consciousness, since it covers various aspects of mental reflection, generalization and transformation of reality. At the same time, we share the idea of the importance of studying consciousness, in addition to meaning, as well as sensual fabric. As L. Zasyekina points out, without studying the mechanisms of generating the value at the level of the sensory tissue, one can not understand the functioning of either the value, or the basic psychic substrate, which it describes - 
consciousness. Therefore, after the scholarly study, we consider an important point in the psychological study of distinguishing meaning not only in the form of a scientific concept or the gain of individual consciousness, but also in the consideration of the functioning of the value at the level of the sensory reflection tissue (Zasyekina, 2005).

According to the famous theory of $\mathrm{L}$. Kohlberg, moral development has three consecutive levels, each of which includes two distinct stages. In general, at a preconventional level, a person fulfills certain requirements, basically fearing punishment; at the conventional level, observance of morality is determined by an attempt to belong to a group, society, to meet their requirements; at the conventional (autonomous) level, the subject independently chooses moral behavior, because he is convinced that living is required according to voluntarily accepted norms. In other words, L. Kohlberg, following J. Piaget, came to the conclusion that rules, norms; laws are created by people on the basis of a mutual agreement and that, if necessary, they can be changed. Therefore, an adult, having passed through all stages of moral development, comes to the realization that there is nothing absolutely correct or incorrect in the world, and that the morality of the act depends not only on its consequences, but on the intentions of the person who carries it out (McLeod Kohlberg's, 2013). The satisfaction of such an idea is confirmed by the results of our study, in particular, that in their real behavior, students often combine different levels of moral consciousness.

In native psychology, the levels and features of the development of moral consciousness of a person in preschool and junior school age are much more thoroughly investigated. At the same time, according to $\mathrm{V}$. Hoffman's position, the main process of moral development of the person falls on the teenage age. Revaluation of values, as stressed by V. Hoffman, is the central point of moral growth in adolescence. Moral development, according to the researcher, is based on three partially matching paths. The first is based on the anxiety of deterrence that is socially proper behavior caused by fear of punishment. The second way embodies the moral perspective, which combines the ability of the individual to understand and share the feelings of others with the ability of cognitive potential. The third way determines the moral growth of adolescents and youth, and it is realized through the development of thinking at the level of formal operations. However, three types of moral growth are not chronological stages. According to V. Hoffman, they can coexist both in adolescence and in adulthood (Hoffman, 2000).

Concerning the specifics of moral consciousness formation in adolescence, the corresponding period is a stage of personality's moral self-acting. Characteristic for him is the conscious, voluntary subordination of his own behavior to moral principles. The main moral tumors in this period are independent judgments, beliefs and views independent of the assessments of other people, as well as the ability to apply them in practice.

4. According to M. Shakhov, for example, during the student period, the process of cardinal neoplasm in the moral sphere is largely completed; the morals of young men can already be compared in their content with the morals of an adult. Moral thinking becomes deeper and dialectic, and moral assessments acquire a relatively objective character. The sense of moral duty normally covers all spheres of activity and is characterized as conscious, persistent and multifaceted. The degree of influence of moral feelings on the individual and collective honor of boys is also increasing, which is reflected in personal intolerance to immoral deeds (Shakhov, 2016: 192-197).

The results of our study of students' moral consciousness, specifically with the preconventional, conventional and postconventional levels of its development, made it possible to determine the features of associative and connotative meanings at the appropriate levels. In other words, the psycho-semantic structure of the moral consciousness of student youth has been studied and interpreted depending on the levels of its development, which makes it possible to talk about more specific features of moral thinking, feelings and behavior of the individual.

\section{Conclusion}

The research determines the methodology of integral psycho-semantic study of students' moral consciousness, which is represented by the philosophy and psychology of meaning as a unit not only rational but also irrational. Accordingly, the psycho-semantic space of students' moral 
consciousness is considered taking into account the intuitive-sensory aspect of the reflection of reality through the determination of its sensory tissue, represented by the set of connotative and associative values.

The results of the theoretical and empirical study of the problem enabled to present the psycho-semantic organization of moral consciousness through a description of its psychosemantic space. In its turn, the psycho-semantic space of the moral consciousness of the student's personality is determined through the individual system of values as the aggregate individual and cultural heritage of the individual, structured appropriately in the sensual fabric of consciousness in the form of associative meanings of the notion of morality, the most frequent of which is conscience.

The connotative values of the notion of conscience at different levels of development of moral consciousness - with leading evaluative and dynamically active connotations in students with preconventional level, strong and ambivalent evaluative connotations for students with a conventional level, positively evaluated and largescale connotations in post-conventional students the level.

Prospects for further research are the study of status-role, gender, more global age aspects of the psycho-semantic space of moral consciousness of the individual. Also relevant in today's difficult situation is the study of the impact on the dimension and content of the corresponding space of the system of thematic training sessions with student youth.

Conflict of interest. We state that there is no conflict of scientific interests.

\section{References}

Artem'eva E. (2007). Psihologija sub'ektivnoj semantiki [Psychology of Subjective Semantics] / E. Artem'eva. - M.: Izd-vo LKI; Smysl, 136. [in Ukrainian]

Bex I. (2006). Vy`xovannya osoby`stosti: sxodzhennya do duxovnosti: nauk. vy`dannya [Education of the person: climb to spirituality: sciences. Edition] / I. Bex. - K.: Ly`bid`,272. [in Ukrainian]

Bory`shevs `ky`j M. (2010). Doroga do sebe: Vid osnov sub'yektnosti do vershy`n duxovnosti: monografiya [Road to yourself: From the basics of subjectivity to the heights of spirituality: monograph] / M.
Bory`shevs`ky`j. - K.: Akademvy`dav, 416. [in Ukrainian]

Hoffman M. L. (2000). Empathy and moral development: implications for caring and justice / M. L. Hoffman- New York: Cambridge University Press,. - 329 p.

McLeod S. Kohlberg's (updated 2013). Stages of Moral Development / S. McLeod. Developmental Psychology- Retrieved from https://www.simplypsychology.org/kohlberg. html

Dermanova I. (2002). Metodika otsenki urovnya razvitiya moral'nogo soznaniya (Dilemmy L.Kolberga) / Diagnostika emotsional'nonravstvennogo razvitiya. Red. i sost. [Methodology for assessing the level of development of moral consciousness (dilemmas L. Kohlberg) / Diagnosis of emotional and moral development. Ed. and collect.]. SPb.: Piter, 103-112. [in Ukrainian]

Osgood C. E. (1975). Cross-cultural universals of affective meaning / C. E. Osgood, M. S. Miron, W. H. May. - Urbana: University of Illinois press, 486.

Pavelkiv R. (2015). Struktura, zmist ta determinanty moral’nogo rozvy`tku osoby`stosti: retrospekciya ta perspekty`vy` [Structure, content and determinants of moral development of personality: retrospection and perspectives] / R. Pavelkiv. Innovaty ka u vy`xovanni [Innovation in upbringing],Vy`p 1, 24-38. [in Ukrainian]

Petrenko V. (2012). Psihosemantika soznanija [Consciousness psycho-semantics] / V. Petrenko. - M: Izd-vo MGU, 208. [in Russian]

Savchy`n M. (2013). Duxovna parady`gma psy`xologiyi: monografiya [Spiritual Paradigm of Psychology: Monograph] / M. Savchy`n - K.: Akademvy`dav, 252.

Shaxov V. (2016). Osobly`vosti rozvy`tku moral ’noyi svidomosti majbutnix psy`xologiv [Features of the development of future psychologists moral consciousness] / V. Shaxov. Naukovi zapy`sky`Vinny`cz kogo derzhavnogo pedagogichnogo universy`tetu imeni My`xajla Kocyuby`ns`kogo. Seriya: pedagogika i psy`xologiya [Scientific notes of the Vinnytsia State Pedagogical University named after Mykhailo Kotsiubynsky. Series: Pedagogy and 
Psychology], Vy`pusk 47, 192-197. [in Zasyekina L. (2005). Strukturno-funktsional'na Ukrainian]

Vlasova O., Meniailo V.( 2016). The impact of adult persons' values on the characteristics of moral choice . Gospodarka Rynek Edukacja, Vol 17, №3.. $\quad-$ organizatsiya intelektu: Monografiya [Structural-functional organization of intelligence: Monograph] / L. Zasyekina. Ostrog: Nats. un-tu «Ostroz'ka akademiya», http://ojs.edukacja.wroc.pl/index.php/GRE/ar 370.

$\underline{\text { ticle/view/159 }}$ 